\title{
The Comparison of Different Surface Preparation Methods in Terms of Shear Bond Strength of Tri-ceram Porcelain- titanium Alloy
}

\author{
Tri-ceram Porselen ve Titanyum Alaşımı Arasındaki Makaslama \\ Bağlantı Direnci Üzerine Farkı Yüzey Uygulamalarının Etkisi \\ (1) Berivan Dündar Yılmaz ${ }^{1}$, (1) Ayşe Meşe², (1) Eylem Kaya²
}

${ }^{1}$ Dicle University Faculty of Dentistry, Department of Prosthodontics, Diyarbakır, Turkey

${ }^{2}$ Mersin Dental Hospital, Mersin, Turkey

Keywords

Shear bond strength, titanium alloy, surface preparation, Tri-ceram porcelain

Anahtar Kelimeler

Makaslama kopma direnci, titanyum alaşımı, yüzey pürüzlendirme, Tri-ceram porselen

Received/Geliş Tarihi : 25.04.2018

Accepted/Kabul Tarihi : 02.10.2018

doi:10.4274/meandros.galenos.2018.70783

Address for Correspondence/Yazışma Adresi: Berivan Dündar Yılmaz MD,

Dicle University Faculty of Dentistry,

Department of Prosthodontics, Diyarbakır, Turkey

E-mail : berivandndr@yahoo.com

ORCID ID: orcid.org/0000-0002-5471-555X

(C) Meandros Medical and Dental Journal, Published by Galenos Publishing House.

This is article distributed under the terms of the Creative Commons Attribution NonCommercial 4.0

International Licence (CC BY-NC 4.0).

\begin{abstract}
Objective: Several studies have been made to evaluate effects of the surface preparation on shear bond strength (SBS) of titanium-porcelain complex. However, a completed picture has not been obtained yet. Therefore, such studies appear frequently on recent literature. The purpose of this study is to determine a simple method providing strong SBS and using fewer parameters.

Materials and Methods: Sixty titanium samples were equally divided into five groups. Group 1: Control (C). Group 2: Airborne-particle abrasion with $250 \mu \mathrm{Al}_{2} \mathrm{O}_{3}$ (250 $\mu$ AbPA). Group 3: Etching with $10 \% \mathrm{HCl}(10 \% \mathrm{HCl})$. Group 4: Etching with $\mathrm{Nd}$ :YAG Laser at 6W (Nd6). Group 5: Etching with Nd:YAG laser at $7 \mathrm{~W}$ (Nd7).

Results: Mean SBS value of C (10.69 MPa) was close to that of $250 \mu$ AbPA (10.57 $\mathrm{MPa})$. The mean value of $10 \% \mathrm{HCl}(19.37 \mathrm{MPa})$ was nearly twice higher than $\mathrm{C}$, whereas those of laser groups ( $8.89 \mathrm{MPa}$ and $8.77 \mathrm{MPa}$ ) were smaller than $\mathrm{C}$. There was no overlap between SBS values of samples etched with $10 \% \mathrm{HCl}$ and those of other samples. Multiple comparisons indicated a significant difference between acid group and others $(p=0.00)$. Laser groups were different from control, too. The failure mode of $\% \mathrm{HCl}$ group was $67 \%$ adhesive and $33 \%$ mix, while those of other groups were cohesive or mix.

Conclusion: Titanium surfaces etched with $10 \% \mathrm{HCl}$ provides significantly strong SBS values. This method requires only the use of aqueous solution of $10 \% \mathrm{HCl}$, and boiling process for 30 minutes. Such a simplicity suggests that etching with 10\% $\mathrm{HCl}$ provides a very simple surface preparation method which involves in use of fewer parameters.
\end{abstract}

Öz

Amaç: Yüzey pürüzlendirme işlemlerinin titanyum porselen bağlantısının kopma direnci üzerine etkilerini değerlendiren birçok çalışma yapılmıştır. Buna rağmen henüz, bu alandaki yöntemlerin standardizasyonu sağlanamamıştır. Bu nedenle son yıllarda bu konuyla ilgili çalışmalara sıkça rastlanmaktadır. Bu çalışmanın amacl, yüzey uygulama metodları ve doğru parametreleri kullanarak kopma direnci sonuçlarını değerlendirmektir. 
Gereç ve Yöntemler: Altmış titanyum örnek 5 gruba eşit sayıda bölündü. Grup 1: Kontrol, grup 2: Al203 (250 $\mu$ m) ile kumlama, grup 3: Asit (\%10 HCl) ile pürüzlendirme, grup 4: $6 \mathrm{~W}$ lazer $(\mathrm{Nd}: Y A G)$ uygulama, grup 5: $7 \mathrm{~W}$ lazer (Nd:YAG) uygulama.

Bulgular: Kontrol grubunun ortalama değerleri (10,69 MPa), kumlama grubuyla (10,57 MPa) yakın bulundu. Asit grubunun ortalama değerleri (19,37 MPa) önemli ölçüde kontrol grubundan fazla bulunurken, lazer grupları değerleri (8,89 MPa ve 8,77 MPa) kontrol grubundan düşük bulundu. Çoklu karşılaştırma testi sonucunda asit grubuyla diğer gruplar arasında anlamlı bir fark bulundu $(p<<0,05)$. Altı W'luk lazer uygulaması dışındaki gruplarla kontrol grubu arasında anlamlı bir fark bulunmadı. Asitle pürüzlendirme grubunda \%75 adeziv ve \%25 miks kopma görülürken diğer gruplarda kohesiv ve miks kopma görüldü. Adeziv kopma tipinin ortalama makaslama bağlanma direnci değeri (20,31 MPa), kohesiv (9,48 MPa) ve miks (10,90 MPa) tipleri değerlerinden yüksek elde edildi. Adesiv kopmanın değerleri istatistiksel olarak diğerlerinden farklı bulundu $(p<<0,05)$.

Sonuç: Titanyum yüzeyinin \%10 HCl asit ile pürüzlendirilmesi güçlü bir makaslama kopma direnci göstermektedir. Bununla, titanyum yüzeyinin asitle pürüzlendirilmesinde uygun bir konsantrasyon olduğunu önerilmektedir.

\section{Introduction}

Several studies have been carried out to investigate the effects of surface preparation on shear bond strength (SBS) of metal-porcelain complex. The SBS values for titanium-porcelain complex have been evaluated by several methods such as acid etching (1-17), alumina airborne-particle abrasion (7-14,1730), laser irradiation $(6,15,16,22,27,30)$, fluoride etchant application $(8,9,12,13)$, nanotechnology $(10)$, machining/milling/thermic treatments $(8,9,13,23,26,31)$ and cooperative use of simple surface preparation methods $(2-4,9)$. The SBS has also been investigated for the influence of various parameters such as acid types and concentrations (2-4,9), treatment with and without vacuum (3), laser types $(6,16,30)$, radiation power of laser irradiation $(15,27 ; 30)$, size of $\mathrm{Al}_{2} \mathrm{O}_{3}$ particles $(22,23,25,26,28)$, resin cements/ bonding agents $(3,16,17,21,25,26,32-35)$, surface coating $(20,24,36,37)$, interfacial oxidation (38$40)$, ceramic types $(5,7,15,41,42)$. Duration and temperature for surface preparation $(2,5,8,9,13,15)$, firing temperature $(20,43)$, storage in water and water loading $(7,9,11,16,26,27,41,44)$, thermocycling $(8,13,16,18,25,26)$, distance in airborne abrasion (13), area fraction of adherent porcelain (19) and crosshead speed of universal testing machine $(13,14,22,24)$. In addition, several review papers have been published in this field $(42,45-47)$

Different materials, diferent methods, different experimental conditions, various parameter settings, and combination of several methods for the surface preparation have yielded different values of the SBS. Depending on experimental conditions and chosen parameters, even contradictive results have been obtained in some studies $(1,6,13,14,16,17,22,27-29)$. In the other words, a completed picture has not been obtained yet. Therefore, the studies on the SBS of titanium-ceramic complex are still interest of clinical research, and such studies appear frequently on the recent literature $(5,10,11,13,14,18,28-30,35,42)$. For these reasons, a new study done by using the simple surface preparation methods and specific parameters may contribute to complementary studies in this field.

The aim of this in vitro study was to reveal simple surface preparation methods providing strong SBS for Tri-ceram porcelain-titanium complex. The hypothesis of the study was to obtain confirmative results contributing to the studies on the strong SBS For these purposes, the SBS values between titanium Tri-ceram porcelain complex were obtained by simple surface preparation methods such as acid etching, alumina airborne-particle abrasion and laser etching. Some particular parameters for each method were also chosen. The effects of these methods on the SBS between a titanium and porcelain were compared.

\section{Materials and Methods}

\section{Sample Preparation and Measurements}

Titanium bars (ASTM F67-00; Titanium Industries, Inc, Rockaway, NJ) were sectioned with a lathe (computer numerical control auto lathe type SA-12 S/N 0910; Star Micronics Co, Ltd, Shizuoka, Japan) into 60 specimens, with $2.2 \mathrm{~mm}$ length and $5.7 \mathrm{~mm}$ in diameter. All specimens were machine cut from long metal rods to the same specified dimensions. No specific surface treatment was performed for the machined surface group, which served as the control group (C). The samples were equally divided into five groups for surface preparation (12 samples for each group).

The airborne-particle-abraded surface specimens (12 samples) were abraded with alumina particles 
$(250 \mu \mathrm{m})$ with a dental airborne-particle-abrasion unit (Micro-blaster; Daedong Industrial Co, Ltd, Daegu, Korea). The air pressure was set at 2 bar, and the distance between the nozzle tip and the specimen surface was maintained at $15 \mathrm{~mm}$, during the airborne-particle abrasion, for 20 seconds (10 scans in 20 seconds, at the rate of 1 scan every 2 seconds.

The acid-etched surface specimens were subjected to chemical surface treatment by submerging the specimens in a $10 \%$-by weight aqueous solution of $\mathrm{HCl}$ (DC Chemical Co, Ltd, Seoul, Korea) in a heat-resistant glass container and boiling for 30 minutes, taking care to avoid contact between specimens.

The laser-etched surface specimens were treated using a custom-made pulsed Nd:YAG laser (Jenoptic Laser Optik Systeme $\mathrm{GmbH}$, Jena, Germany). The titanium surfaces of the specimens were irradiated by the linear movement of a glass fiber of the $\mathrm{Nd}$ :YAG laser at a power setting of $7 \mathrm{~W}$ and $6 \mathrm{~W}$, representing energy and frequency levels of $120 \mathrm{~mJ}$ with $50-\mathrm{Hz}$ frequency

The groups were as follows:

Group 1 (C): Control (no treatment).

Group 2 (250 m AbPA): Airborne-particle abrasion with Al2O3 particles $(250 \mathrm{~m})$.

Group $3(\% 10 \mathrm{HCl})$ : Surfaces etched with $\% 10 \mathrm{HCl}$

Group 4 (Nd6): Surfaces etched with Laser (Nd:YAG laser) at $6 \mathrm{~W}$ irradiation power.

Group 5 (Nd7): Surfaces etched with Laser (Nd:YAG laser) at $7 \mathrm{~W}$ irradiation power.

Before application of porcelain, the samples were replaced in ultrasonic cleaning apparatus at $80^{\circ} \mathrm{C}$ for 10 minutes. Then, they were washed with distilled water. Low-fusing porcelain (Tri-ceram; Esprident $\mathrm{GmbH}$, Ispringen, Germany) was used in this investigation. Firing temperature and times were in accordance with the manufacturer's specifications and directions. Heat pretreatment of the specimens was performed immediately after cleaning procedures in a dental porcelain furnace (Austromat 3001; Dekema $\mathrm{GmbH}$, Freilassing, Germany). Opaque porcelain was mixed as a powder and liquid until it reached a creamy consistency, then applied in 2 uniform coats with a brush on each treated porcelain-bearing surface. After the opaque porcelain firing cycle $\left(795^{\circ} \mathrm{C}\right)$, the dentin porcelain was subsequently formed on the opaque layer, using a specially designed silicone mold, and fired at $500{ }^{\circ} \mathrm{C}$ to $755^{\circ} \mathrm{C}$ with a heat rate of $55^{\circ} \mathrm{C} /$ min under a vacuum of $72 \mathrm{~cm} / \mathrm{Hg}$. The firing shrinkage was compensated for with a second body porcelain application, until an approximately 4-mm thick porcelain layer was obtained. A glazing procedure was not performed. Porcelain application for all of the specimens was performed by a single dental technician. The Tri-ceram were then adhered to the surface treated samples using Clearfil SE Protect (Kuraray).

The following treatments were applied to the prepared samples:

1- The samples were mechanically loaded $(20.000$ cycles; $50 \mathrm{~N}$ load; distilled water at $37^{\circ} \mathrm{C}$ ).

2- The samples were thermocycled (3.000 cycles; 5-55 ${ }^{\circ} \mathrm{C}$, dwell time: $30 \mathrm{sec}$ ).

To evaluate the bond strength of the interface between the metal and ceramic, the shear bond test, which has been described by other investigators, was performed. For the shear bond test, a special stainless steel device was fabricated. This device enabled the specimen to be held firmly during the shear bond test. The device containing the metal ceramic specimen was placed in a tensile testing machine (micro 500, type U4000, Maywood Instruments. Limited Basingstoke Hants. England). The power loading point was $5 \mathrm{~mm}$ far from metal porcelain connection, while the speed of loading was $5 \mathrm{~mm} /$ minute The load was applied until fracture of the metal-porcelain interface occurred, and the maximum load at fracture was expressed in megapascals (MPa). After fracture, scanning electron microscope (SEM) (JSM-6700F; JEOL Ltd, Tokyo, Japan) observation was once more performed to evaluate the nature of the fractured surfaces. Three photomicrographs with $\times 2000$ magnification were made of different regions of the treated surface and the fractured surface of each specimen.

\section{Statistical Analysis}

Results were presented as the mean + standard deviations (SD). One-way ANOVA followed by Games-Howell post hoc test $(\alpha=0.05)$ was used for comparisons. $\mathrm{P}<0.05$ was considered as statistically significant.

\section{Results}

Mean SBS values and SD of all groups were given in Table 1. The mean values of $C$ are close to that of alumina airborne-particle abrasion. The mean value of acid group is almost twice higher than control, 
whereas those of laser groups are smaller than control. There is no overlap between maximum SBS values for $250 \mu$ AAbPA and minimum SBS values for acid etching. There is large overlap among the SBS of other groups.

Multiple comparisons of groups are given in Table 2. It is seen that the SBS of $10 \% \mathrm{HCl}$ etching group is highly significantly different than those of other groups $(p=0.00)$. There is no significant difference between $250 \mathrm{~m} \mathrm{AbPA}$ and control, and also between $250 \mathrm{~m} \mathrm{AbPA}$ and Nd6 ( $p>0.05) .250 \mathrm{~m} \mathrm{AbPA}$ is different from Nd7 $(p=0.05)$. In addition, $C$ is different from both laser groups $(p<0.05)$.

The numbers of adhesive, cohesive and mix failure modes, determined by SEM, were 8, 21 and 31 respectively. Adhesive failure mode was only observed in 8 of 12 samples etched with acid, but cohesive mode was found in all groups other than $10 \% \mathrm{HCl}$. Mixed failure mode was exist in all groups.

SEM Images Obtained From Surface Preparations

SEM images of C, $250 \mu \mathrm{AbPA}, 10 \% \mathrm{HCL}$ and $\mathrm{Nd} 7$ are shown in Figures 1,2,3 and 4, respectively The

Table 1. The mean values of shear bond strength together with standard deviation for investigated groups

\begin{tabular}{|l|l|l|l|} 
Groups & Number & $\begin{array}{l}\text { Mean SBS values } \\
\pm \text { SD (MPa) }\end{array}$ & min-max \\
\hline Control (C) & 12 & $10.69+1.40$ & $7.20-12.10$ \\
\hline $250 \mu \mathrm{AbPA}$ & 12 & $10.57+1.47$ & $8.40-12.90$ \\
\hline $10 \% \mathrm{HCl}$ & 12 & $19.37+2.99$ & $14.40-25.40$ \\
\hline $\mathrm{Nd} 6$ & 12 & $8.89+1.11$ & $7.30-10.90$ \\
\hline $\mathrm{Nd7}$ & 12 & $8.88+2.34$ & $6.60-13.80$ \\
\hline $\begin{array}{l}\text { SBS: Shear bond strength, SD: Standard deviation, MPa: Megapascal, } \\
\text { min: Minimum, max: Maximum }\end{array}$ \\
\hline
\end{tabular}

\begin{tabular}{|l|l|l|}
\hline \multicolumn{2}{|l|}{ Table 2. Statistical significances between groups } \\
\hline \multicolumn{2}{|l|}{ Comparison between groups } & Significance (p) \\
\hline \multirow{3}{*}{$10 \% \mathrm{HCl}$} & $\mathrm{C}$ & 0.000 \\
& $250 \mu \mathrm{AAbPA}$ & 0.000 \\
& $\mathrm{Nd6}$ & 0.000 \\
& $\mathrm{Nd7}$ & 0.000 \\
\hline $250 \mathrm{~mA}$ AbPA & $\mathrm{C}$ & 0.998 \\
& $\mathrm{Nd} 6$ & 0.075 \\
& $\mathrm{Nd7}$ & 0.050 \\
\hline $\mathrm{C}$ & $\mathrm{Nd} 6$ & 0.049 \\
& $\mathrm{Nd7}$ & 0.032 \\
\hline Nd6 & $\mathrm{Nd7}$ & 0.990 \\
\hline
\end{tabular}

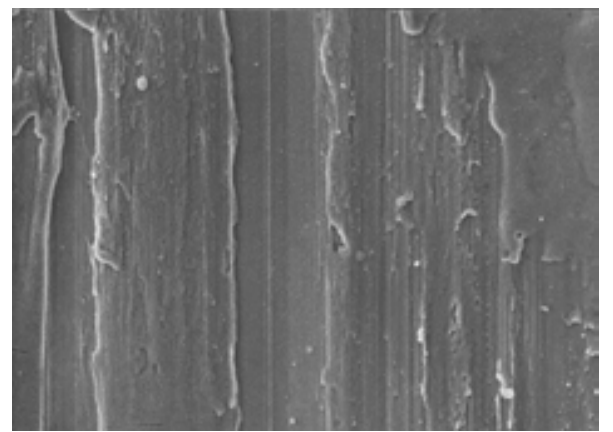

Figure 1. Scanning electron microscope image of control group

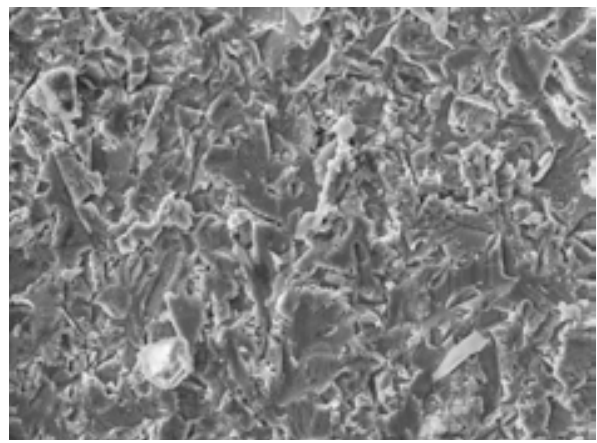

Figure 2. Scanning electron microscope image of airborneparticle ablated with alumina particle group

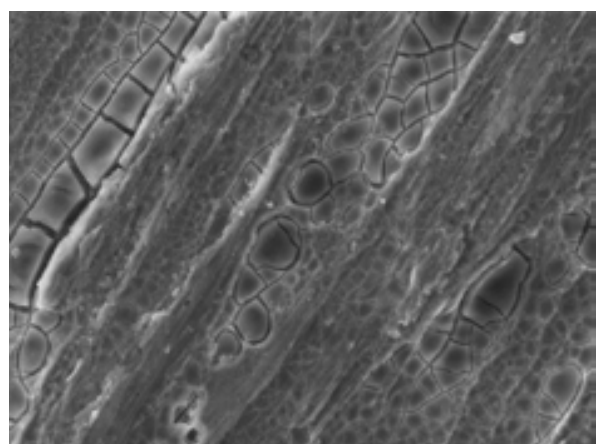

Figure 3. Scanning electron microscope image of acid etched group

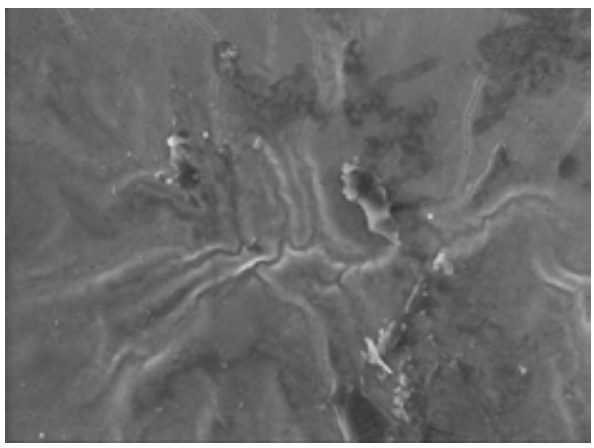

Figure 4. Scanning electron microscope image of laser group at 7 Watt 
image for Nd6 was not given for the sake of simplicity. Smooth surface was observed for both $\mathrm{C}$ and Nd6. The roughest surface was observed in $250 \mu$ AbPA. In addition to these, laser irradiated samples at $\mathrm{Nd} 7 \mathrm{had}$ a smoother surface. Nevertheless some detonation points and black areas were found on SEM images of the Nd7.

\section{Discussion}

The success of the porcelain-fused-alloy restoration depends widely on the strong bonding between porcelain and the titanium. In the current work, the titanium surface treatment with $10 \% \mathrm{HCl}$ has provided strong SBS values, and acid etching was found to be more effective than alumina airborne-particle abrasion, laser etching and $\mathrm{C}$. In fact, acid etching has been indicated as mostly quite effective method for increasing SBS in titanium-porcelain system (1$4,12,16,18)$. Therefore, the present results obtained with $10 \% \mathrm{HCl}$ are in consistent with the previous studies related to surface acid treatment. However, in the previous studies, the surface acid etching has been reinforced by other treatment methods $(2,4,16)$. Also titanium surfaces have been treated by using highly concentrated acids (e.g. $48 \% \mathrm{H}_{2} \mathrm{SO}_{4}$ ) different than $\mathrm{HCl}$ $(3,12,16)$. On the contrary, even $1 \mathrm{~N}$ (about $3 \%) \mathrm{HCl}$ is known to erodes the titanium surface effectively and to provide increasing SBS values (18).

Airborne-particle abrasion has been noted to weaken the metal ceramic bonding in some studies $(1,6,24)$. Alternative methods to the airborne-particle abrasion have also presented $(1,3,6,10,12,27)$. However, airborne-particle abrasion with certain size of Al2O3 (e.g. 110 and $250 \mathrm{~m} \mathrm{Al2O3)} \mathrm{is} \mathrm{known}$ to increase bonding in the metal ceramic system $(6,13,18,29)$. It was noted that SB increased as particle size increased (29). Despite this, the combined use of alumina airborne-particle abrasion with other surface preparation materials and methods has mostly been used to obtain strong SBS $(2,8,9,14,17,19,21,23,26)$. The diversity of SBS values including the current value for $250 \mu \mathrm{AAbPA}$ should be related to parameter settings and experimental conditions. In fact, the strong SBS in the airborne-particle abrasion is dependent on many factors such as particle size of $\mathrm{Al}_{2} \mathrm{O}_{3}$, bonding agent, water storage, etching times, laser welding, metal conditioners, vacuum firing, cooperative use of simple surface preparation methods, thermic treatment, order of cooperative treatment, pressure and angle used $(3,7,13,14,17,18,21,22,24,26,28,31)$.

The Nd:YAG laser etching has been found found to be effective improving bond strength of titaniumceramic system in some studies $(6,15,27)$, whereas lower SBS was obtained by laser irradiation in other studies (16). High variability was observed in adhesion values obtained by laser etching (42). In fact, the efficiency of laser irradiation is dependent on various parameters such as irradiation power, laser type etc. $(15,30)$. For example, Er:YAG and Nd:YAG lasers applied with certain power have yielded the stronger SBS $(27,30)$. However, Nd:YAG laser was found to be more successful than Er:YAG and Ho:YAG lasers for bonding low fusion porcelain to metal alloy (30). In addition to these, laser applications or other surface preparation methods may be more successful when applied to ceramics or other type of metal alloys. The SBS obtained with laser etching or without laser have been found to be strong for the ceramic-Ni-Cr or ceramic- Co-Cr alloys (48-51).

Adhesion is the tendency of dissimilar surfaces to stick to one another. There are many types of forces that can occur when surfaces come in close contact $(48,49)$. Rather than inter molecular forces between dislike molecules, mechanical and chemical forces provide binding of metal to ceramic where failure mode is adhesive. In mechanical binding, a strong bond is formed between the substrate and the adhesive $(48,49)$. Also, Chemical binding is usually the strongest form of adhesion $(48,49)$. Since adhesive failure is dominant on the surfaces treated with $10 \% \mathrm{HCl}$, the current strong mean SBS obtained for titanium-ceramic system should be related to ontrol mechanical or chemical binding.

Smooth surface appearance obtained by SEM for laser irradiation groups are in agreement with the small SBS and cohesive failure mode of these groups. The SEM appearance with relatively rough surface in acid etching group is in consistent with strong adhesive bonding that is likely produced through mechanical or chemical interactions. The roughness in the alumina airborne-particle abrasion may be related to long-distance adhesive interactions since cohesive failure mode is dominant for this case. In addition to these, the detonation points and black areas on SEM images of laser group etched at $7 \mathrm{~W}$ power express that increasing energy creates burning areas. The 
connection between titanium and porcelain becomes weaker in this area. Therefore, the use of a laser at 6 $W$ energy should be more convenient.

As mentioned earlier, variability of the SBS values obtained from titanium-ceramic complex is dependent on surface preparation methods, experimental conditions and parameter settings. Multitude of parameters and conditions requires elimination of some of them which are not providing simple method and strong SBS. In our case, etching titanium surface by using acid requires only the use of aqueous solution of $10 \% \mathrm{HCL}$, and boiling process for 30 minutes. Therefore, it is a very simple method providing significantly strong SBS. Thus the aim or hypothesis of our study was fulfilled.

\section{Conclusion}

Etching titanium surface with $10 \% \mathrm{HCl}$ has provided a strong bonding for titanium-ceramic complex. This suggests that etching with $10 \% \mathrm{HCl}$ provides very simple method for surface preparation of titanium.

Ethics

Ethics Committee Approval: The study were approved by the Dicle University of Local Ethics Committee (protocol number: 2018/7).

Informed Consent: The authors confirm that this article content has no conflict of interest.

Peer-review: Internally peer-reviewed.

\section{Authorship Contributions}

Concept: B.D.Y., A.M., E.Ö., Design: B.D.Y., A.M., E.K., Data Collection or Processing: E.K., Analysis or Interpretation: A.M., Literature Search: E.K., Writing: B.D.Y., A.M., E.K.

Conflict of interest: The authors confirm that this article content has no conflict of interest.

Financial Disclosure: Authors thank to DUAPK (Research Foundation of Dicle University)-06DH-09 for financial support.

\section{References}

1. Reyes MJ, Oshida Y, Andres CJ, Barco T, Hovijitra S, Brown D. Titanium-porcelain system. Part III: effects of surface modification on bond strengths. Biomed Mater Eng 2001; 11: 117-36.

2. Cai Z, Bunce N, Nunn ME, Okabe T. Porcelain adherence to dental cast $\mathrm{CP}$ titanium: effects of surface modifications. Biomaterials 2001; 22: 979-86.

3. Ban S, Taniki T, Sato $H$, Kono $H$, Iwaya $Y$, Miyamoto $M$. Acid etching of titanium for bonding with veneering composite resins. Dent Mater J 2006; 25: 382-90.
4. Troia MG Jr, Henriques GE, Mesquita MF, FragosoWS. The effect of surface modifications on titanium to enable titaniumporcelain bonding. Dent Mater 2008; 24: 28-33.

5. Ramakrishnaiah R, Alkheraif AA, Divakar DD, Matinlinna JP, Vallittu PK. The Effect of Hydrofluoric Acid Etching Duration on the Surface Micromorphology, Roughness, and Wettability of Dental Ceramics. Int J Mol Sci 2016; 17: E822.

6. Kim JT, Cho SA. The effects of laser etching on shear bond strength at the titanium ceramic interface. J Prosthet Dent 2009; 101: 101-6.

7. Menezes $\mathrm{FCH}$, Borges GA, Valentino TA, Oliveira MAHM, Turssi $\mathrm{CP}$, Correr-sobrinho L. Effect of surface treatment and storage on the bond strength of different ceramic systems. Braz J Oral Sci 2009; 8: 119-23.

8. Taira $\mathrm{Y}$, Odatsu T, Sawase T. Effects of a fluoride etchant and a phosphate primer on bonding of veneering composite to Ti-6Al$4 \mathrm{~V}$ alloy for CAD/CAM restorations. J Prosthodont Res 2013; 57 : 30-5.

9. Egoshi T, Taira Y, Soeno K, Sawase T. Effects of sandblasting, $\mathrm{H} 2 \mathrm{SO} 4 / \mathrm{HCl}$ etching, and phosphate primer application on bond strength of veneering resin composite to commercially pure titanium grade 4. Dent Mater J 2013; 32: 219-27.

10. Vignesh, Nayar S, Bhuminathan, Mahadevan, Santhosh S. Comparative evaluation of the three different surface treatments - conventional, laser and Nano technology methods in enhancing the surface characteristics of commercially pure titanium discs and their effects on cell adhesion: An in vitro study. J Pharm Bioallied Sci 2015;7(Suppl 1): S87-91.

11. Shayegh SSH, Amini P, Yaghmai K, Massoumi F, Abbasi K. Comparison of the Effect of Three methods of Porcelain Surface Treatment on Shear Bond Strength of Composite to Porcelain. J Islam Dent Assoc Iran 2016; 28: 72-7.

12. Lim BS, Heo SM, Lee YK, Kim CW. Shear bond strength between titanium alloys and composite resin: sandblasting versus fluoride-gel treatment. J Biomed Mater Res B Appl Biomater 2003; 64: 38-43.

13. Guilherme N, Wadhwani C, Zheng C, Chung KH. Effect of surface treatments on titanium alloy bonding to lithium disilicate glassceramics. J Prosthet Dent 2016; 116: 797-802.

14. Galo R, Frizzas DG, Rodrigues RCS, Ribeiro RF, Mattos MGC. Surface treatment on the shear bond strength of dental ceramics to titanium commercially pure. Eur J Gen Dent 2017; 6: 77-81.

15. Gökçe B, Ozpinar B, Dündar $M$, Cömlekoglu E, Sen BH, Güngör $M A$. Bond strengths of all-ceramics: acid vs laser etching. Oper Dent 2007; 32: 173-8.

16. Akyil MS, Yilmaz A, Karaalioğlu OF, Duymuş ZY. Shear bond strength of repair composite resin to an acid-etched and a laserirradiated feldspathic ceramic surface. Photomed Laser Surg 2010; 28: 539-45.

17. Al Hussaini I, Al Wazzan KA. Effect of surface treatment on bond strength of low-fusing porcelain to commercially pure titanium. J Prosthet Dent 2005; 94: 350-6.

18. Veljee TM, Shruthi CS, Poojya R. Evaluation and comparison of the effect of different surface treatment modifications on the 
shear bond strength of a resin cement to titanium: An in vitro study. J Indian Prosthodont Soc 2015; 15: 308-12.

19. Sadeq A, Cai Z, Woody RD, Miller AW. Effects of interfacial variables on ceramic adherence to cast and machined commercially pure titanium. J Prosthet Dent 2003; 90: 10-7.

20. Lee KM, Cai Z, Griggs JA, Guiatas L, Lee DJ, Okabe T. SEM/EDS evaluation of porcelain adherence to gold-coated cast titanium. J Biomed Mater Res B Appl Biomater 2004; 68: 165-73.

21. Yamada K, Onizuka T, Sumii T, Swain MV. The effect of Goldbonder on the adhesion between porcelain and pure titanium. J Oral Rehabil 2004; 31: 775-84.

22. Galo R, Ribeiro RF, Rodrigues RC, Pagnano Vde O, de Mattos Mda G. Effect of laser welding on the titanium composite tensile bond strength. Braz Dent J 2009; 20: 403-9.

23. de Almeida-Júnior AA, Fonseca RG, Haneda IG, Abi-Rached Fde $O$, Adabo GL. Effect of surface treatments on the bond strength of a resin cement to commercially pure titanium. Braz Dent J 2010; 21: 111-6.

24. Wei AY, Sharma AB, Watanabe LG, Finzen FC. The effects of an airborne-particle abrasion and silica-coating on the bond strength between grooved titanium alloy temporary cylinders and provisional veneering materials. J Prosthet Dent 2011; 105 : 158-63.

25. Iseri U, Ozkurt Z, Kazazoglu E. Shear bond strengths of veneering porcelain to cast, machined and laser-sintered titanium. Dent Mater J 2011; 30: 274-80.

26. Almilhatti HJ, Neppelenbroek KH, Vergani CE, Machado AL, Pavarina AC, Giampaolo ET. Adhesive bonding of resin composite to various titanium surfaces using different metal conditioners and a surface modification system. J Appl Oral Sci 2013; 21: 5906.

27. Akin H, Tugut F, Topcuoglu S, Kirmali O. Effects of sandblasting and laser irradiation on shear bond strength of low-fusing porcelain to titanium. J Adhes Dent 2013; 15: 55-63.

28. Golebiowski M, Wolowiec E, Klimek L. Airborne-particle abrasion parameters on the quality of titanium-ceramic bonds. J Prosthet Dent 2015; 113: 453-9.

29. Moldi Al, Bhandari KS, Nagral S, Deshpandey S, Kulkarni P. Effect of sandblasting on fracture load of titanium ceramic crowns. J Indian Prosthodont Soc 2015; 15: 224-8.

30. Saygın GA, Ozdemir AK, Gorler O. Influence of various laser surface modifications on SBS of titanium and zirconium oxide substructure. CSJ 2017; 38: 245-55.

31. Dundar B, Guzel KG. An analysis of the shear strength of the bond between enamel and porcelain laminate veneers with different etching systems: acid and Er,Cr:YSGG laser separately and combined. Lasers Med Sci 2011; 26: 777-82.

32. Gilbert JL, Covey DA, Lautenschlager EP. Bond characteristics of porcelain fused to milled titanium. Dent Mater 1994; 10: 134-40.

33. Suansuwan N, Swain MV. Adhesion of porcelain to titanium and a titanium alloy. J Dent 2003; 31: 509-18.

34. Chakmakchi M, Eliades $\mathrm{G}$, Zinelis S. Bonding agents of low fusing cpTi porcelains: elemental and morphological characterization. J Prosthodont Res 2009; 53: 166-71.
35. Yang J, Kelly JR, Bailey O, Fischman G. Porcelain-titanium bonding with a newly introduced, commercially available system. J Prosthet Dent 2016; 116: 98-101.

36. Wang RR, Welsch GE, Monteiro O. Silicon nitride coating on titanium to enable titanium-ceramic bonding. J Biomed Mater Res 1999; 46: 262-70.

37. Bieniaś J, Surowska B, Stoch A, Matraszek H, Walczak M. The influence of $\mathrm{SiO} 2$ and $\mathrm{SiO} 2-\mathrm{TiO} 2$ intermediate coatings on bond strength of titanium and Ti6Al4V alloy to dental porcelain. Dent Mater 2009; 25: 1128-35.

38. Kimura $\mathrm{H}$, Horng $\mathrm{CJ}$, Okazaki $\mathrm{M}$, Takahashi J. Oxidation effects on porcelain-titanium interface reactions and bond strength. Dent Mater J 1990; 9: 91-9.

39. Hautaniemi JA, Herø $\mathrm{H}$. Juhanoja JT. On the bonding of porcelain on titanium. J Mater Sci: Mater Med 1992; 3: 186-91.

40. Wang RR, Fung KK. Oxidation behavior of surface-modified titanium for titanium-ceramic restorations. J Prosthet Dent 1997; 77: 423-34.

41. Vásquez VZ, Ozcan M, Kimpara ET. Evaluation of interface characterization and adhesion of glass ceramics to commercially pure titanium and gold alloy after thermal- and mechanicalloading. Dent Mater 2009; 25: 221-31.

42. García-Sanz V, Paredes-Gallardo V, Mendoza-Yero O, CarbonellLeal M, Albaladejo A, Montiel-Company JM, et al. The effects of lasers on bond strength to ceramic materials: A systematic review and meta-analysis. PLoS One 2018; 13: e0190736.

43. Haag $P$, Andersson M, Nilner K. Porcelain bonding to titanium with two veneering principles and two firing temperatures. Swed Dent J 2013; 37: 143-51.

44. Homann F, Waddell JN, Swain MV. Influence of water, loading rate and bonder on the adhesion of porcelain to titanium. J Dent 2006; 34: 485-90.

45. Könönen $M$, Kivilahti J. Fusing of dental ceramics to titanium. J Dent Res 2001; 80: 848-54.

46. Haag $P$, Nilner K. Bonding between titanium and dental porcelain: a systematic review. Acta Odontol Scand 2010; 68: 154-64.

47. Jamet A, Ghazali MJ, Razali M, Otsuka Y, Surface Modifications and Their Effects on Titanium Dental Implants. Biomed Res Int 2015; 2015: 791725.

48. Adhesion of polymers, Polymer properties data base available at http://polymerdatabase.com/

49. Springman RM., Mechanical and Chemical Effects in Adhesion of Thin Shell Structures with Applications in Wafer Bonding and Adhesion of Living Cells (2009), PhD thesis, University of Pennsylvania. Publicly Accessible Penn Dissertations. 4. http:// repository. upenn.edu/ edissertations/4

50. Külünk T, Kurt M, Ural Ç, Külünk Ş, Baba S. Effect of different airabrasion particles on metal-ceramic bond strength. J Dent Sci 2011; 6: 140-6.

51. Deepak K, Ahila SC, Muthukumar B, Vasanthkumar M. Comparative evaluation of effect of laser on shear bond strength of ceramic bonded with two base metal alloys: an in-vitro study. Indian J Dent Res 2013; 24: 610-5. 